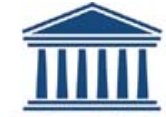 \\ UNIVERSITEIT \\ GENT
}

biblio.ugent.be

The UGent Institutional Repository is the electronic archiving and dissemination platform for all UGent research publications. Ghent University has implemented a mandate stipulating that all academic publications of UGent researchers should be deposited and archived in this repository. Except for items where current copyright restrictions apply, these papers are available in Open Access.

This item is the archived peer-reviewed author-version of:

Title: Synthesis and Evaluation of Amino-Modified $\alpha$-GalCer Analogues

Authors: Trappeniers, Matthias; Chofor, René; Aspeslagh, Sandrine; Li, Yali; Linclau, Bruno; Zajonc, Dirk; Elewaut, Dirk; Van Calenbergh, Serge

In: ORGANIC LETTERS, 12(13), 2928 - 2931 (2010), DOI 10.1021/ol100934z 


\title{
Synthesis and Evaluation of Amino-Modified $\alpha$-GalCer Analogues
}

\author{
Matthias Trappeniers, ${ }^{\dagger}$ René Chofor, ${ }^{\dagger}$ Sandrine Aspeslagh, ${ }^{\ddagger}$ Yali \\ Li, " Bruno Linclau, " Dirk M. Zajonc," Dirk Elewaut, ${ }^{+}$and Serge Van \\ Calenbergh ${ }^{\dagger}$ *
}

\begin{abstract}
Laboratory for Medicinal Chemistry (FFW), Ghent University, Harelbekestraat 72, 9000 Ghent (Belgium), Laboratory for Molecular Immunology and Inflammation, Department of Rheumatology, Ghent University Hospital, Ghent University, De Pintelaan 185, 9000 Ghent (Belgium), Division of Cell Biology, La Jolla Institute for Allergy and Immunology, La Jolla, CA (USA), and School of Chemistry, University of Southampton, Highfield, Southampton SO17 1BJ (UK)
\end{abstract}

Serge.vancalenbergh@ugent.be

Received Date (will be automatically inserted after manuscript is accepted)

\section{ABSTRACT}

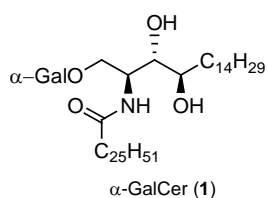

$\alpha$-GalCer (1)

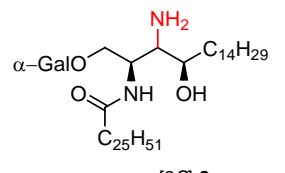

$[3 S]-2$

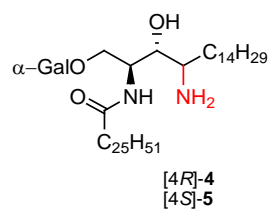

$[4 R]-4$

$\alpha$-GalCer analogues featuring a phytoceramide 3- and 4-amino group have been synthesized. A Mitsunobu reaction involving phthalimide was employed for the introduction of the amino groups at the 3- and 4-positions of suitable phytosphingosine-derived precursors. The influence of these modifications on the interaction with the T-cell receptor of NKT cells was investigated, as well as the capacity of the amino-modified analogues to induce a cytokine response after in vivo administration.

In the past decade, glycolipids have gained increasing interest as immune modulatory agents due to their role in the defence against microbial infections, tumor immunosurveillance and the maintenance of immune tolerance. ${ }^{1}$ In that context, the most extensively studied glycolipid is $\alpha$-GalCer (1, aka KRN7000), ${ }^{2}$ of which high specificity

\footnotetext{
${ }^{\dagger}$ Laboratory for Medicinal Chemistry, Ghent University.

‡ Department of Rheumatology, Ghent University.

|| Division of Cell Biology, La Jolla Institute for Allergy and Immunology.

" School of Chemistry, University of Southampton.

${ }^{1}$ Reviews: (a) Wu, D.; Fujio, M.; Wong, C.H. Bioorg. Med. Chem. 2008, 16, 1073. (b) Savage, P.B.; Teyton, L.; Bendelac, A. Chem. Soc. Rev. 2006, 35, 771.

2 (a) Morita, M. ; Motoki, K.; Akimoto, K.; Natori, T.; Sakai, T.; Sawa, E.; Yamaji, K.; Koezuka, Y.; Kobayashi, E.; Fukushima, H. J. Med. Chem. 1995, 38, 2176. (b) Natori, T.; Koezuka, Y.; Higa, T.
}

for CD1d, a cell surface glycoprotein constitutively expressed by antigen presenting cells, is well-established. Upon recognition of the $\alpha$-GalCer-CD1d complex by their semi-invariant T-cell receptor (TCR), Natural Killer $\mathrm{T}$ (NKT) cells are activated, resulting in the rapid release of T helper 1 (Th1) and T helper 2 (Th2) cytokines. The concomitant release of Th1 and Th2 cytokines, which antagonize each other's effects, is believed to limit $\alpha$ GalCer's therapeutic outcome. Hence, the development of analogues capable of inducing a biased Th1 or Th2 response is highly promising. ${ }^{3}$

Tetrahedron Lett. 1993, 34, 5591. (c) Natori, T.; Morita, M.; Akimoto, K.; Koezuka, Y. Tetrahedron 1994, 50, 2771.

${ }^{3}$ Berkers, C. R.; Ovaa, H. Trends Pharmacol. Sci. 2005, 26, 252. 
Crystal structures of human ${ }^{4}$ and mouse ${ }^{5}$ CD1d complexed with $\alpha$-GalCer or the ternary structures also comprising the human ${ }^{6}$ and mouse ${ }^{7}$ NKT TCR reveal that the galactose ring is well ordered and extends above the surface of a lipid-binding groove. Several hydrogen bonds between 1 and CD1d are assumed to anchor $\alpha$-GalCer in a proper orientation for recognition by the TCR. ${ }^{8}$ Asp-80 was found to interact with both secondary hydroxy groups (i.e., 3-OH and 4-OH) of the phytosphingosine backbone. A key interaction of the subsequent NKT TCR binding involves a hydrogen bond between the TCR Arg-95 residue and the same 3-OH group.

The hypothesis stating that the Th1-Th2 balance is determined by the overall stability of the CD1dglycolipid-TCR complex is a matter of debate. Many analogues, typically obtained by modifying the apolar regions of $\mathbf{1}$, have been synthesised in order to investigate this relationship, ${ }^{9,10,11}$ but recent studies also point toward the importance of the mode of glycolipid loading into CD1d and the rate of glycolipid dissociation from CD1d in the lysosomes. ${ }^{12}$

From the X-ray data, it can be concluded that $\alpha$ GalCer's 3-OH is a crucial group as it interacts both with CD1d and the TCR. Hence we proposed to investigate the 3- and 4-amino-3-(4-)deoxy analogues $\mathbf{2 - 5}$, as it was anticipated that ionic interactions would be established with the CD1d Asp-80, leading to increased complex stability. On the other hand, the interaction with the TCR would also be affected by such modifications since a 3ammonium group can no longer act as hydrogen bond acceptor and the inductive effect of the 4-ammonium group was expected to severely weaken the hydrogen bond acceptor capacity of the 3-OH.

\footnotetext{
${ }^{4}$ Koch, M.; Stronge, V.S.; Shepherd, D.; Gadola, S.D.; Mathew, B.; Ritter, G.; Fersht, G.S.; Schmidt, R.R.; Jones, E.Y.; Cerundolo, V. Nat. Immunol. 2005, 6, 819.

${ }^{5}$ Zajonc, D.M.; Cantu, C.; Mattner, J.; Zhou, D.; Savage, P.B.; Bendelac, A.; Wilson, I.A.; Teyton, L. Nat. Immunol. 2005, 6, 810.

${ }^{6}$ Borg, N.A.; Wun, K.S.; Kjer-Nielsen, L.; Wilce, M.C.J.; Pellicci, D.G.; Koh, R.; Besra, G.S.; Bharadwaj, M.; Godfrey, D.I.; McCluskey, J.; Rossjohn, J. Nature 2007, 448, 44.

Pellicci, D.G.; Patel, O.; Kjer-Nielsen, L.; Pang, S.S.; Sullivan, L.C.; Kyparissoudis, K.; Brooks, A.G.; Reid, H.H.; Gras, S.; Lucet, I.S.; Koh, R.; Smyth, M.J.; Mallevaey, T.; Matsuda, J.L.; Gapin, L.; McCluskey, J.; Godfrey, D.I.; Rossjohn, J. Immunity 2009, 31, 47-59.

${ }^{8}$ Henon, E.; Dauchez, M.; Haudrechy, A.; Banchet, A. Tetrahedron 2008, 64, 9480 .

(a) Miyamoto, K.; Miyake, S.; Yamamura, T. Nature 2001, 413 531. (b) Goff, R.D.; Gao, Y. ; Mattner, J.; Zhou, D.; Yin, N.; Cantu, C.; Teyton, L.; Bendelac, A.; Savage, P.B. J. Am. Chem. Soc. 2004, 126, 13602.

${ }^{10}$ Yu, K.O.A.; Im, J.S.; Molano, A.; Dutronc, Y.; Illarionov, P.A.; Forestier, C.; Fujiwara, N.; Arias, I.; Miyake, S.; Yamamura, T.; Chang, Y.T.; Besra, G.S.; Porcelli, S.A. Proc. Natl. Acad. Sci. USA 2005, 102, 3383.

${ }^{11}$ (a) Liang, P.H.; Imamura, M.; Li, X.; Wu, D.; Fujio, M.; Guy, R.T.; Wu, B.C.; Tsuji, M.; Wong, C.H. J. Am. Chem. Soc. 2008, 130 , 12348. (b) Chang, Y.J. ; Huang, J.R.; Tsai, Y.C.; Hung, J.T.; Wu, D.; Fujio, M.; Wong, C.H.; Yu, A.L. Proc. Natl. Acad. Sci. USA 2007, 104 10299.

12 (a) . Im, J.S.; Arora, P.; Bricard, G.; Molano, A.; Venkataswamy, M.M.; Baine, I.; Jerud, E.S.; Goldberg, M.F.; Baena, A.; Yu, K.O.A.; Ndonye, R.M.; Howell, A.R.; Yuan, W.; Cresswell, P.; Chang, Y.-t.; Illarionov, P.A.; Besra, G.S.; Porcelli, S.A. Immunity, 2009, 30, 888898. (b) Bai, L.; Sagiv, Y.; Freigang, S.; Yu, K.O.A.; Teyton, L.; Porcelli, S.; Savage, P.B.; Bendelac, A. Proc. Natl. Acad. Sci. 2009, 106, 10254-10259.
}

Synthetic procedures towards the desired 2,3-diamino1,4-butanediol or 2,4-diamino-1,3-butanediol aglycon scaffolds are scarce. Noteworthy is the recently reported enantioselective synthesis of a $O$-1-protected 4-deoxy-4azido-2-phthalimido-D-ribo-phytosphingosine, involving a regioselective opening of a cyclic sulfate. ${ }^{13}$ The structure of prumycin, an antibiotic isolated in 1971 that is synthetically accessible, ${ }^{14}$ contains a 2,4-diamino-1,3butanediol moiety with a configuration matching that of the desired L-lyxo analogue 5.

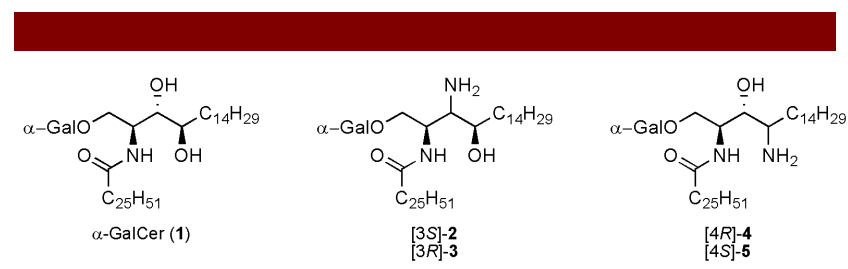

Figure 1. Structures of KRN7000 (1) and amino-modified analogues (2-5).

However, for the synthesis of the four desired glycosyl acceptors, it was decided to use a common strategy starting from D-ribo-phytosphingosine, which is now readily available from a yeast fermentation process.

The synthesis of the 3-amino-3-deoxy- $\alpha$-GalCer epimers is shown in Scheme 1. D-ribo-phytosphingosine was converted to the two C3-epimeric 1,4-diprotected azido-phytosphingosine derivatives 6-7. ${ }^{15}$ Unfortunately, all attempts to effect invertive phthalimide introduction via a Mitsunobu reaction resulted in an elimination sidereaction to give 8 , regardless of the configuration at C-3 or the O-1 protecting group (see Supporting information). The $E$-configuration of the double bond in $\mathbf{8}$ was confirmed by a ROESY experiment.

Given the electron withdrawing azido group presumably promoted the undesired elimination reaction, it was decided to first convert the azido group to the required long-chain amido moiety. Hence, Staudinger reduction, followed by acylation with hexacosanoic acid and EDC gave the ceramides 9 and 10 , which were now successfully converted to the phthalimides via a Mitsunobu protocol to afford the desired 3-phthalimidophytosphingosine acceptors $\mathbf{1 1}$ and $\mathbf{1 2}$ after deprotection of the trityl group with zinc(II)-dibromide.

Mukaiyama glycosidation ${ }^{16}$ of 3 -phthalimido-D-ribophytosphingosine 11 and 3-phthalimido-D-xylophytosphingosine 12 with galactosyl fluoride 13 afforded the desired 3-amino- $\alpha$-GalCer analogues 2 and 3, after final deprotection operations.

\footnotetext{
${ }^{13}$ Llaveria, J.; Diaz, Y.; Matheu, M.I.; Castillon, S. Org. Lett. 2008, 11, 205.

${ }^{14}$ Hasegawa, A.; Aritake, N.; Kiso, M. Carbohydr. Res. 1976, 51, C10.

${ }^{15}$ Trappeniers, M.; Goormans, S.; Van Beneden, K.; Decruy, T.; Linclau, B.; Al-Shamkhani, A.; Elliott, T.; Ottensmeier, C.; Werner, J.M.; Elewaut, D.; Van Calenbergh, S. ChemMedChem 2008, 3, 1061.

${ }^{16}$ Mukaiyama, T.; Murai, Y.; Shoda, S. Chem. Lett. 1981, 431.
} 
Scheme 1. Synthesis of the 3-amino-3-deoxy- $\alpha$-GalCer analogues 2 and 3

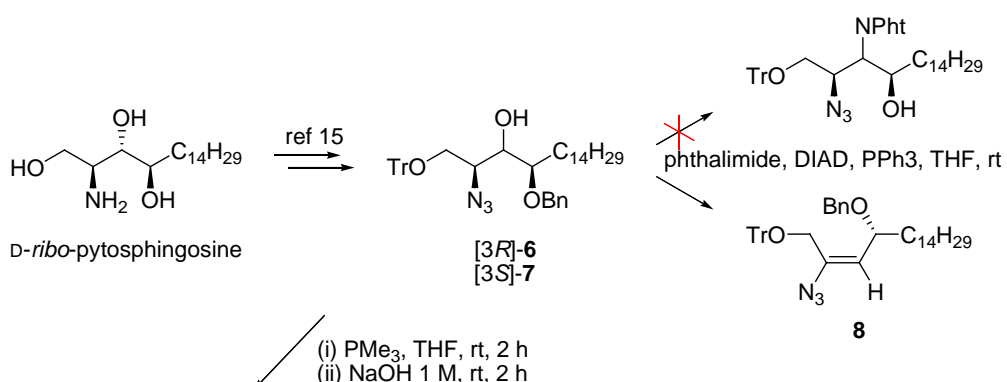

(ii) $\mathrm{NaOH} 1 \mathrm{M}, \mathrm{rt}, 2 \mathrm{~h}$

(iii) $\mathrm{C}_{25} \mathrm{H}_{51} \mathrm{COOH}, \mathrm{EDC}, \mathrm{CH}_{2} \mathrm{Cl}_{2}$, rt, $18 \mathrm{~h}$

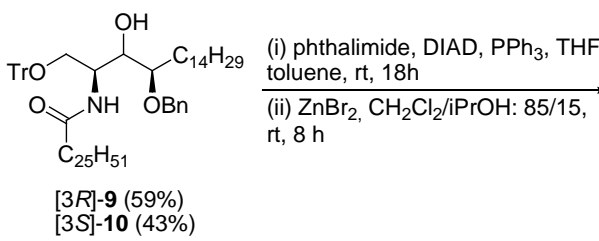

$[3 R]-9(59 \%)$
$[3 S]-10(43 \%)$

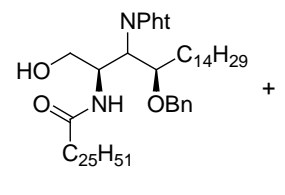

$[3 S]-11(39 \%)$

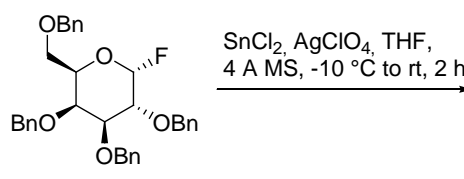

13

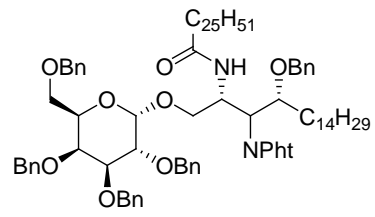

[3S]-14 (81\%)

$[3 R]-15(61 \%)$

(i) $\mathrm{H}_{2}$ Pd black, $\mathrm{CHCl}_{3} / \mathrm{EtOH}: 1 / 1,3 \mathrm{~h}$

(ii) $\mathrm{MeNH}_{2}$ in $\mathrm{EtOH}(8 \mathrm{M})$, reflux, $2 \mathrm{~d}$

Scheme 2. Synthesis of the D-ribo and L-lyxo glycosidation acceptors 22 and 23

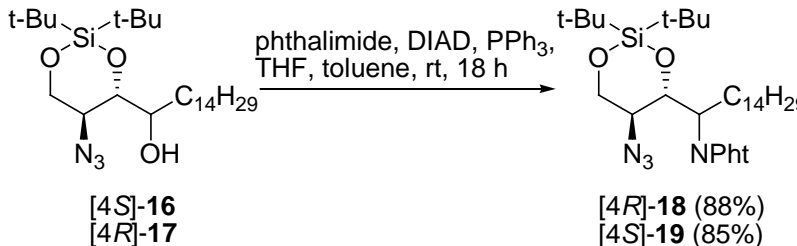

(i) HF.pyridine, THF/pyridine, $0{ }^{\circ} \mathrm{C}, 0.5 \mathrm{~h}$ (ii) $\mathrm{TrCl}, \mathrm{DMAP}$, pyridine, $70{ }^{\circ} \mathrm{C}, 22 \mathrm{~h}$

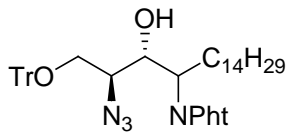
(i) $\mathrm{BnBr}, \mathrm{NaH}, \mathrm{DMF}$,
$0^{\circ} \mathrm{C}-\mathrm{rt}, 14 \mathrm{~h}$
(ii) $\mathrm{ZnBr}_{2}, \mathrm{CH}_{2} \mathrm{Cl}_{2} / \mathrm{iPrOH}$ :
85/15, rt, overnight<smiles>CCCCC(N)C(Br)C(=N)O</smiles>

[4R]-22 (78\%)

[4S]-23 (87\%)
Towards the synthesis of the 4-amino-4-deoxy- $\alpha$ GalCer analogues 4 and 5, the 4-phtalimido-substituted phytosphingosine precursors with the natural D-ribo- (22) and L-lyxo-configuration (23) were first prepared in 5 steps from the advanced intermediates 16 and 17 (Scheme 2), again accessible from D-ribo-phytosphingosine.

TMSOTf-promoted galactosidation of the 4-deoxy-4phthalimido-D-ribo-phytosphingosine 22 with the trichloroacetimidate donor $24^{17}$ afforded the $\alpha$-glycoside without notable formation of the $\beta$-glycoside (Scheme 3 ). Interestingly, Staudinger reduction of the glycoside 25 led to the intramolecular formation of the amidine 27, presumably via the aza-Wittig mechanism. ${ }^{18}$ To circumvent this side-reaction, it was decided to perform a protecting group switch to give the corresponding dibenzylamino group (28), which allowed uncomplicated Staudinger reduction to give the 2- $\mathrm{NH}_{2}$ group. Subsequent acylation with hexacosanoic acid and final deprotection afforded the desired 4-amino-4-deoxy- $\alpha$ galactosyl-D-ribo-phyto-ceramide 4.

Similarly, glycosidation of the 4-deoxy-4-phthalimidoL-lyxo-phytosphingosine 23 afforded the $\alpha$-glycoside 26 in $81 \%$ yield. In this case Staudinger reduction led to the desired free amine and a relatively small amount of the amidine, which could be efficiently removed after acylation of the former. Debenzylation, followed by final deprotection of the phthalimide with methylamine, gave the desired 4-amino-4-deoxy- $\alpha$-galactosyl-L-lyxophytoceramide 5 .

${ }^{17}$ (a) Plettenburg, O.; Bodmer-Narkevitch, V.; Wong, C.H. J. Org. Chem. 2002, 67, 4559; (b) Koeman, F.A.W.; Kamerling, J.P.; Vliegenthart, J.F.G. Tetrahedron 1993, 49, 5291; (c) Figueroa-Peréz, S.; Schmidt, R.R. Carbohydrate Res. 2000, 328, 95.

${ }^{18}$ Molina, P.; Vilaplasa, M.J. Synthesis 1994, 1197. 
Scheme 3. Synthesis of the 4-amino-4-deoxy- $\alpha$-GalCer analogues 4 and 5

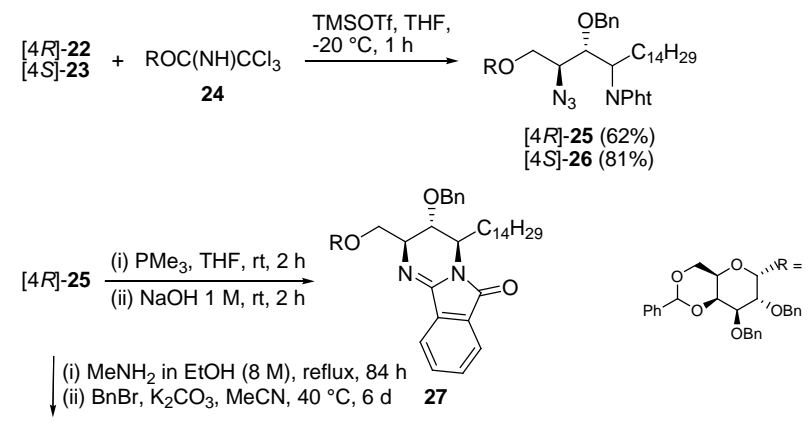

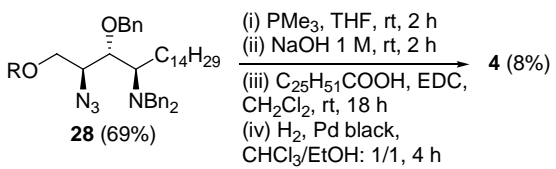

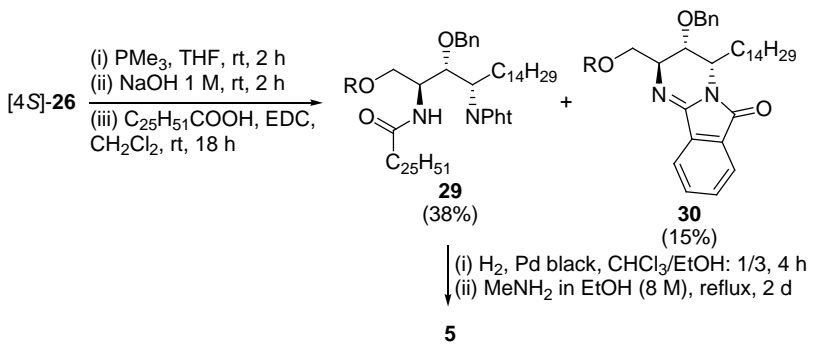

To compare the cytokine profile induced by the aminomodified analogues with $\alpha$-GalCer, serum cytokine levels were measured after IP injection of glycolipids 1-5 into $\mathrm{C} 57 \mathrm{Bl} / 6$ mice (Figure 2). Following injection of the 3amino epimers 2 and 3, low levels of IL-4 were detected, and als IFN- $\gamma$ levels were drastically lower compared to $\alpha$-GalCer. On the other hand, a trend towards a more moderate reduction of IFN- $\gamma$ was observed after stimulation with the 4-amino epimers 4 and 5 .

Surface plasmon resonance was used to measure the binding kinetics of a soluble mouse Va14i TCR for the complex of mCD1d plus 1,2 and 4. Compared to $\alpha$ GalCer $\left(K_{D}=12.8 \mathrm{nM}\right)$, the TCR showed a 13-fold reduced binding affinity to CD1d loaded with the 3-amino analogue $2\left(\mathrm{~K}_{\mathrm{D}}=163 \mathrm{nM}\right)$ and a 125-fold drop in affinity for the 4-CD1d complex $\left(K_{D}=1.7 \mu M\right)$. While the association of the TCR is $2 x$ slower for analog 4 $\left(k_{\mathrm{a}}=2.21 \times 10^{4} 1 / \mathrm{Ms}\right)$ and $6.5 \mathrm{x}$ slower for $2\left(\mathrm{k}_{\mathrm{a}}=6.1 \times 10^{4}\right.$ $1 / \mathrm{Ms}$ ) the TCR dissociates $25 \mathrm{x}$ faster from the amino analog $4\left(\mathrm{k}_{\mathrm{d}}=0.037 \mathrm{x} 1 / \mathrm{s}\right)$ and $7.5 \mathrm{x}$ faster for $2(0.01 \mathrm{x} 1 / \mathrm{s})$. Therefore, the 3'- and 4'-amino modification significantly affect the overall stability of the TCR interaction.

In summary, we showed that, despite its reasonable affinity for the TCR when complexed with CD1d, analogue 2 shows a very small cytokine response, while an opposite trend is observed for analogue 4. These findings conflict with current hypotheses, which, however have been inferred mainly from studies involving analogues with altered aliphatic chains. While such alterations are hidden from the TCR contact surface, this is different for the amino modifications in this study. Indeed, as highlighted by the crystal structure of the ternary mCD1d- $\alpha$-GalCer-TCR, the $3-\mathrm{OH}$ group is not only interacting with CD1d, but also exposed to the TCR to form a hydrogen bond with Arg-95 (of the CDR3 $\alpha$ unit). Possibly, when protonated, the 3-amino group of 2 interacts unfavorably with Arg-95, thereby leading to suboptimal activation of the TCR.

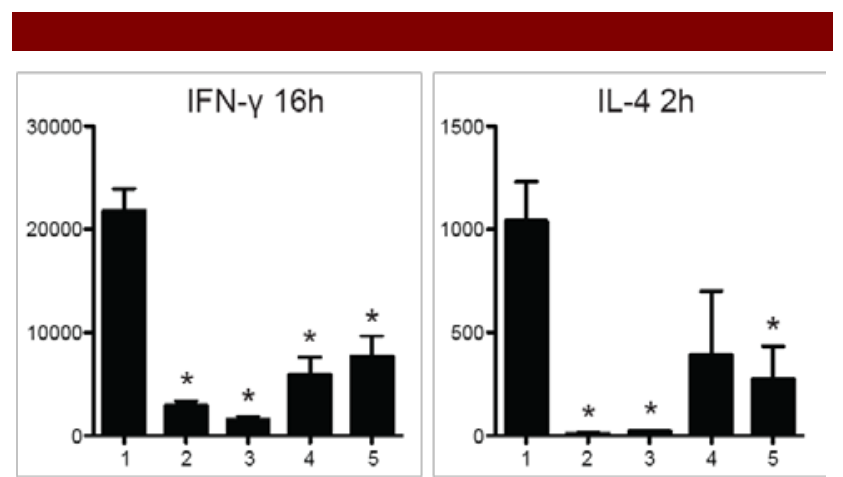

Figure 2. INF- $\gamma$ and IL-4 secretion after intraperitoneal injection of $\alpha$-GalCer (1) and $\mathbf{2 - 5}$ in mice ( ${ }^{*} P<0.01$ vs $\alpha$ GalCer).

In conclusion, the present amine-modified analogues indicate that, although TCR affinity probably accounts to some degree for the quality of responses mediated by iNKT cells, subtle changes to $\alpha$-GalCer may afford analogues with diminished capacity to provoke activation of the iNKT cells, despite good affinity for the TCR.

Acknowledgment M.T. and S.A. are aspirants of the Fund for Scientific Research-Flanders (F.W.O.Vlaanderen). Financial support by F.W.O., Stichting tegen Kanker, and Cancer Research Technologies is gratefully acknowledged. D.M.Z is recipient of an investigator award from the Cancer Research Institute and supported by NIH grant AI074952.

Supporting Information Available Experimental procedures for the preparation of 2-5, for the in vivo stimulation with $\alpha$-GalCer-analogues and the SPR studies. This material is available free of charge via the Internet at htpp://pubs.acs.org. 